\title{
Perencanaan Rainwater Harvesting dan Pengolahan Air Limbah di Pondok Pesantren Mambaul Ulum Bata-Bata Pamekasan
}

\author{
Fadlilatin Nailah dan Ali Masduqi \\ Departemen Teknik Lingkungan, Fakultas Teknik Sipil, Lingkungan, dan Kebumian, Institut \\ Teknologi Sepuluh Nopember (ITS) \\ e-mail: masduqi@its.ac.id
}

\begin{abstract}
Abstrak-Pondok pesantren Mambaul Ulum terletak di Dusun Bata-Bata, Desa Panaan, Kecamatan Palengaan, Kabupaten Pamekasan. Pondok pesantren Mambaul Ulum Bata-Bata (MUBA) memiliki luas wilayah sebesar $\pm \mathbf{1 0}$ ha dan jumlah santri pada tahun 2016 sebanyak 10.216 orang. Banyaknya jumlah santri menyebabkan tingginya kebutuhan air bersih dan produksi air limbah. Permasalahan yang sering dihadapi adalah kurangnya pasokan air bersih pada musim kemarau dan belum adanya pengolahan terhadap air limbah. Sehingga air limbah langsung dibuang ke sungai. Oleh karena itu, direncanakan adanya rainwater harvesting dan pengolahan air limbah yang dilengkapi dengan analisis kelayakan ekonominyaPerencanaan ini dimulai dengan adanya studi literatur. Selanjutnya dilakukan pengumpulan data baik primer maupun sekunder. Data yang didapat selanjutnya diolah dan dianalisis untuk menunjang perencanaan rainwater harvesting dan pengolahan air limbah. Perencanaan ini dibagi menjadi dua blok utama, yaitu di pondok putra dan pondok putri. Di pondok putri, didapat perhitungan perencanaan rainwater harvesting dengan kapasitas $347,76 \mathrm{~m}^{3}$ dan $469,52 \mathrm{~m}^{3}$ di pondok putra. Sementara itu, pengolahan limbah dengan menggunakan Anaerobic Baffled Reactor (ABR) di pondok putri ABR dengan 4 kompartemen dengan dimensi total sebesar 21,2 x 4,3 x 4,3 m. Sedangkan di pondok putra direncanakan ABR dengan 3 kompartemen dan dimensi total sebesar 23,43 x 4,3 x 3,8 m. Berdasarkan analisis kelayakan ekonomi dengan Net Present Value (NPV) dan Benefit and Cost Ratio (BCR), perencanaan ini memenuhi syarat sehingga layak untuk diaplikasikan.
\end{abstract}

Kata Kunci-Air Limbah, Anaerobic Baffled Reactor, Benefit and Cost Ratio, Net Present Value, Pondok Pesantren Mambaul Ulum Bata-Bata, Rainwater Harvesting.

\section{PENDAHULUAN}

$\mathrm{P}$ ONDOK pesantren Mambaul Ulum terletak di Dusun Bata-Bata, Desa Panaan, Kecamatan Palengaan, Kabupaten Pamekasan. Pondok pesantren Mambaul Ulum Bata-Bata (MUBA) memiliki luas wilayah sebesar \pm 10 ha. Pondok pesantren MUBA memiliki beberapa jenjang pendidikan, mulai dari pondok kecil (khusus anak berumur 312 tahun), MTs, MA, dan SMK. Pada tahun 2016, jumlah santri di pondok pesantren MUBA sebanyak 10.216 orang [1].

Banyaknya jumlah santri menyebabkan kebutuhan air bersih yang tinggi di pondok pesantren MUBA. Selama ini pasokan air bersih yang digunakan berasal dari sumber mata air Kapt. Blumbungan dan Sumber Cangkreng. Menurut data dari Dinas Pengairan Kabupaten Pamekasan tahun 2014 menyatakan bahwa debit yang dihasilkan oleh sumber Kapt. Blumbungan sebesar 28 L/detik dan Sumber Cangkreng sebesar 33 L/detik terbilang cukup. Di sisi lain, dua sumber mata air ini juga memasok air bersih untuk wilayah Kecamatan Palengaan lainnya. Kondisi yang demikian menyebabkan kurangnya pasokan air bersih saat musim kemarau tiba. Hal ini disebabkan karena menurunnya debit sumber mata air yang digunakan untuk pemasok air bersih ke lingkungan pesantren.

Ada beberapa upaya untuk mengatasi krisis air. Di Nigeria, krisis air diatasi dengan melakukan rainwater harvesting $(R W H)$ pada setiap rumah dengan mengandalkan konstruksi atap yang dilengkapi talang air hujan [2]. Sebanyak 95\% rumah di wilayah Katpadi,Tamil Nadu, India juga sudah menerapkan rainwater harvesting dengan Rooftop Harvesting System (RTHS). Suplai air dengan RTHS didapat dari perkalian antara luas atap rumah, curah hujan dan nilai koefisien run off [3]. Rainwater harvesting tidak hanya diterapkan di wilayah pemukiman penduduk namun juga diterapkan di kompleks pendidikan. Misalnya di SSVP Sanstha, Vidyanagari, Dhule, India. Kompleks kampus ini menggunakan rainwater harvesting untuk menyuplai kebutuhan air bersih. Hal ini dilakukan juga untuk konservasi air tanah yang semakin menipis [4].

Alternatif penggunaan rainwater harvesting sesuai untuk diterapkan di wilayah pondok pesantren MUBA. Hal ini dikarenakan curah hujan di wilayah Kecamatan Palengaan cukup tinggi yaitu sebesar $1771 \mathrm{~mm} /$ detik dengan hari hujan sebesar 108 mm/detik [5]. Konstruksi bangunan pesantren baik sekolah maupun asrama juga sudah dilengkapi dengan talang air hujan. Selain itu, air hujan memiliki kualitas yang baik dengan TSS 0,87-8,09 sehingga mudah dalam pengolahanny [6].

Sementara itu, air limbah yang dihasilkan dari kegiatan santri di pondok pesantren MUBA juga belum diolah dengan baik. Selama ini limbah tersebut langsung dibuang ke badan air. Banyaknya air limbah yang dibuang ke badan air akan menyebabkan pencemaran air [7]. Limbah domestik mengandung sampah padat dan cair yang berasal dari limbah rumah tangga dengan beberapa sifat utama yaitu : mengandung bakteri, mengandung bahan organik dan padatan tersuspensi sehingga BOD (Biological Oxygen Demand) biasanya tinggi, padatan organik dan anorganik yang mengendap di dasar perairan menyebabkab oksigen terlarut (DO) rendah, dan mengandung bahan terapung dalam bentuk suspensi sehingga mengurangi kenyamanan dan menghambat laju fotosintesis [8].

ABR merupakan salah satu jenis pengolahan suspended growth yang memanfaatkan sekat (baffle) dalam pengadukan yang bertujuan memungkinkan terjadinya kontak antara air limbah dan biomass. Pengolahan ini adalah pengolahan yang 
murah dari segi operasional, sebab tidak diperlukan penggunaan energi listrik, dan memiliki efisiensi removal organik yang cukup baik. Kemampuan mengolah zat padat bergantung pada batas pemberian makan (feed line) atau kompartemen pertama. Hal ini dapat pula diatasi dengan penambahan unit yang dapat membantu pemisahan zat padat [9].

Dalam perencanaan ini, air yang tertampung dalam penampung air hujan diuji terlebih dahulu dengan tujuan apakah membutuhkan pengolahan lebih lanjut atau tidak. Sedangkan air limbah diuji terlebih dahulu untuk mengetahui efektivitas penyisihan polutan yang terkandung didalamnya. Pemilihan unit pengolahan yang tepat dan efisien diharapkan dapat memenuhi kebutuhan pasokan air bersih dan menurunkan pencemaran lingkungan serta meningkatkan kesehatan santri pondok pesantren MUBA Pamekasan.

\section{METODE PENELITIAN}

\section{A. Kualitas Air}

Perencanaan ini dimulai dengan melakukan analisis kualitas air hujan dan air limbah. Sampling dilakukan di dua tempat yaitu di blok pondok putra dan pondok putri. Setelah itu, sampel yang didapat diuji di laboratorium untuk diketahui kualitasnya berdasarkan beberapa parameter. Adapun parameter yang digunakan untuk air hujan antara lain kekeruhan, TSS, pH,suhu, dan kesadahan. Sementara untuk air limbah antara lain $\mathrm{pH}$, BOD, COD, TSS, dan Minyak dan lemak.

\section{B. Kuantitas Air}

1. Air hujan

Menghitung kuantitas air hujan yang dapat ditampung dengan cara mengetahui catchment area terlebih dahulu dengan cara :

a. Atap Flat atau datar

Luas atap $=[p+2$ (overstek) $] \times[1+2$ (overstek) $]$

b. Atap berbentuk pelana atau perisai

Luas atap $=[p+2$ (overstek) $] \times[1+2$ (overstek) $] / \cos \alpha$

Kemudian menghitung banyaknya air hujan yang dapat ditampung, dengan cara :

$$
\mathrm{V}=(\mathrm{Cr} \times \mathrm{I} \times \mathrm{A}) / 1000
$$

Dimana $\mathrm{Cr}=$ koeffisien run off

$$
\begin{aligned}
& \mathrm{I}=\text { curah hujan } \\
& \mathrm{A}=\text { cacthment area }
\end{aligned}
$$

Selanjutnya dihitung kapasitas tangki penampung dengan cara : $\quad \mathrm{Vt}=\mathrm{V} \times \mathrm{B}$, dimana

$$
\begin{aligned}
& \mathrm{Vt}=\text { volume bak penampung }\left(\mathrm{m}^{3}\right) \\
& \mathrm{V}=\text { volume air hujan yang dapat diterima }\left(\mathrm{m}^{3}\right) \\
& \mathrm{B}=\text { Kebutuhan air dalam satu bulan }\left(\mathrm{m}^{3}\right)
\end{aligned}
$$

Perhitungan kapasitas tangki dapat menentukan dimensi dari unit penampung air hujan yang berupa ground reservoir.

2. Air limbah

Air limbah yang dihasilkan merupakan 80\% dari kebutuhan air bersih di pondok pesantren. Adapun kebutuhan air bersih di pondok didapat dari data dari dinas PU tahun 1996, yaitu sebesar 80 L/orang.hari.

Selanjutnya dilakukan perencanaan air limbah dengan menggunakan unit $\mathrm{ABR}$

\section{HASIL DAN PEMBAHASAN}

Perencanaan ini dibagi menjadi dua blook utama, yaitu asrama pondok putra dan asrama pondok putri, dengan jumlah santri pada masing-masing blok sebanyak 5869 dan 4347 orang.

\section{A. Perencanaan $R W H$}

Kualitas air hujan yang telah diuji menyatakan bahwa air hujan masih berada di bawa baku mutu, sehingga tidak memerlukan pengolahan tambahan. Hasil kualitas air hujan ditunjukkan oleh Tabel 1.

Tabel 1.

Kualitas Air Hujan

\begin{tabular}{lcccc}
\hline \hline Parameter & Satuan & $\begin{array}{c}\text { Baku Mutu } \\
\text { Air }\end{array}$ & $\begin{array}{c}\text { Hasil } \\
\text { Analisis }\end{array}$ & Metode Analisis \\
\hline Kekeruhan & NTU & 5 & 1,5 & Turbidimetri \\
TSS & $\mathrm{mg} / \mathrm{L}$ & 500 & 115 & Gravimetri \\
$\mathrm{pH}$ & - & $6,5-8,5$ & 6,8 & $\mathrm{pH}$ meter \\
Suhu & ${ }^{\circ} \mathrm{C}$ & Suhu udara \pm 3 & 29,2 & Termometer \\
Kesadahan & $\mathrm{mg} / \mathrm{L}$ & 500 & 75 & Titrasi kompleksometri \\
\hline \hline
\end{tabular}

Nilai kesadahan air hujan di pondok pesantren rendah namun masih berada di rentang aman kesadahan air yaitu 75-500 mg/L. Selanjutnya menghitung volume air yang dapat ditampung. Dan didapatkan hasil pada Tabel 2.

Tabel 2.

Volume air hujan yang dapat ditampung

\begin{tabular}{lcccc}
\hline \hline \multicolumn{1}{c}{ Blok } & $\begin{array}{c}\text { Catchment } \\
\left.\text { Area } \mathbf{( m}^{2}\right)\end{array}$ & Cr & $\begin{array}{c}\text { I } \\
(\mathbf{m m} / \text { tahun) }\end{array}$ & $\begin{array}{c}\text { Volume } \\
\left.\mathbf{( m}^{3}\right)\end{array}$ \\
\hline Madrasah Aliyah & 1023,557 & 0,9 & 1771 & 1631,447 \\
Madrasah Ibtidaiyah & 582,864 & 0,9 & 1771 & 929,027 \\
Pondok Putri & 3657,153 & 0,9 & 1771 & 5829,136 \\
Pondok Putra & 9341,201 & 0,9 & 1771 & 14888,940 \\
\hline \hline
\end{tabular}

Dari perhitungan menunjukkan bahwa total air hujan yang dapat ditampung sebanyak 21.862,813 $\mathrm{m}^{3} /$ tahun. Namun pada perencanaan ini yang ditampung dalam reservoir hanya yang berada pada pondok putra dan putri. Sehingga dihitung kapasitas tangki penampung, dan didapatkan hasil pada Tabel 3.

Tabel 3.

Kapasitas tangki penampung air hujan

\begin{tabular}{ccccc}
\hline \hline Blok & $\begin{array}{c}\text { Jumlah } \\
\text { orang }\end{array}$ & $\begin{array}{c}\text { Volume } \\
\left(\mathbf{m}^{\mathbf{3}}\right)\end{array}$ & $\begin{array}{c}\text { Kebutuhan air } \\
\left(\mathbf{m}^{3} / \text { orang. Hari) }\right.\end{array}$ & $\begin{array}{c}\text { Kapasitas } \\
\text { tangki }\left(\mathbf{m}^{\mathbf{3}}\right)\end{array}$ \\
\hline Pondok Putri & 4347 & 13,708 & 0,08 & 347,76 \\
Pondok Putra & 5869 & 39,841 & 0,08 & 469,52 \\
\hline \hline
\end{tabular}

Dimensi tangki penampung direncanakan memiliki kedalaman 4m, dengan perbandingan panjang: lebar sebesar 1:1. Oleh karena itu, didapat dimensi pada pondok putri sebesar 10 x 10 x 4 m, sedangkan pada pondok putra sebesar 11 x 11 x $4 \mathrm{~m}$.

\section{B. Perencanaan $A B R$}

Kualitas air limbah yang akan diolah berdasarkan hasil uji di laboratorium seperti yang ditunjukkan pada Tabel 4 .

$$
\text { Tabel } 4 .
$$

Kualitas Air Limbah Pondok Pesantren

\begin{tabular}{lccccc}
\hline \hline Blok & $\begin{array}{c}\text { TSS } \\
\text { (mg/L) }\end{array}$ & $\begin{array}{c}\text { BOD } \\
\text { (mg/L) }\end{array}$ & $\begin{array}{c}\text { COD } \\
\text { (mg/L) }\end{array}$ & pH & $\begin{array}{c}\text { Minyak dan } \\
\text { Lemak (mg/L) }\end{array}$ \\
\hline Pondok Putri & 334 & 240 & 394 & 7,65 & 46 \\
Pondok Putra & 190 & 90 & 148 & 7 & 16 \\
\hline \hline
\end{tabular}

Adapun jumlah air limbah yang harus diolah merupakan $80 \%$ dari kebutuhan air bersih. Kebutuhan air bersih di pondok putri sebesar 347,76 $\mathrm{m}^{3} /$ hari dan di pondook putra sebesar 469,52 $\mathrm{m}^{3} /$ hari. Sehingga debit air limbah di pondok putri sebesar $278,21 \mathrm{~m}^{3} /$ hari dan pada pondok putra sebesar $375,61 \mathrm{~m}^{3} /$ hari. 
Direncanakan dengan td 3 jam, sehingga effisiensi removal BOD dan COD sebesar 44\% dan TSS sebesar 65\%. Dengan waktu pengurasan lumpur selama 3 tahun, maka didapat dimensi kompartemen 1 sebesar 4 x 3,6 x 3,5 m di pondok putri sedangkan di pondok putra sebesar 4 × 5,9 x 3 m. Adapun jumlah kompartemen pada pondok putri sebanyak 4 buah dan di pondok putra sebanyak 3 buah. Dimensi kompartemen 2 pada pondok putri yaitu 4 × 4 × 3,5 m sementara pondok putra 5,3 x 4 × 3 m. Menentukan efisiensi removal BOD, COD, dan TSS menggunakan parameter beban organik (Organic Loading Rate), BOD strength, suhu, jumlah kompartemen, dan Hydraulic Retention Time (HRT). Didapat pada pondok putri efisiensi removal BOD sebesar 63\%, efisiensi removal COD sebesar 49\%, dan efisiensi TSS sebesar 65\%. Sementara di pondok putra efisiensi removal BOD yaitu 63\%, efisiensi removal COD yaitu 58\% dan efisiensi removal TSS yaitu 65 .

\section{KESIMPULAN/RINGKASAN}

Berdasarkan perencanaan yang telah dilakukan, maka dapat diambil kesimpulan sebagai berikut:

1. Kualitas air hujan di pondok pesantren Mambaul Ulum Batabata Pamekasan ditinjau dari semua parameter yang digunakan masih di bawah baku mutu, yaitu kekeruhan sebesar 1,5 NTU, kadar TSS sebesar $115 \mathrm{mg} / \mathrm{L}$, pH sebesar 6,8, suhu sebesar $29,2{ }^{\circ} \mathrm{C}$, dan kesadahan sebesar $75 \mathrm{mg} / \mathrm{L}$. Sementara kualitas air limbah yang terdiri dari pondok putri dan pondok putra, ditinjau dari parameter BOD,COD,TSS, berada diatas baku mutu air sehingga perlu diolah sebelum dibuang ke lingkungan.

2. Perencanaan rainwater harvesting di pondok pesantren Mambaul Ulum Bata-bata Pamekasan dilakukan terhadap bangunan yang sudah memiliki talang air hujan yang kemudian ditampung dalam reservoir yang terletak di pondok putri dan pondok putra. Adapun kapasitas masingmasing reservoir di pondok putri dan pondok putra sebesar $347,76 \mathrm{~m}^{3}$ dan 469,52 $\mathrm{m}^{3}$. Adapun perencanaan air limbah dilakukan dengan unit Anaerobic Baffled Reactor (ABR) yang terletak masing-masing di pondok putri dan putra. Adapun dimensi total ABR pada pondok putri yaitu 21,2 x 4,3 x 4,3 m. Sedangkan dimensi total ABR di pondok putra sebesar 23,43 x 4,3 x 3,8 m.
3. Pada perencanaan rainwater harvesting diperkirakan memakan biaya sebesar Rp495.070.200,00. Sementara perencanaan air limbah dengan $\mathrm{ABR}$, di pondok putri menghabiskan Rp1.048.850.060,00 dan Rp1.133.447.720,00 di pondok putra.

4. Hasil analisis kelayakan ekonomi dengan menggunakan $\mathrm{Net}$ Present Value (NPV) dan Benefit and Cost Ratio (BCR) menyatakan bahwa pada proyek ini layak diaplikasikan.

\section{UCAPAN TERIMA KASIH}

Penulis mengucapkan terimakasih kepada pihak Departemen Teknik Lingkungan dan Ustadz Kusairi,S.Pd.I selaku ketua dewan ma'hadiyah Pondok Pesantren Mambaul Ulum BataBata Pamekasan atas segala dukungan dan izin yang telah diberikan.

\section{DAFTAR PUSTAKA}

[1] Dewan Ma'hadiyah Pondok Pesantren MUBA, "Data Adiministrasi Pondok Pesantren Mambaul Ulum Bata-Bata,” Pamekasan, 2016.

[2] V. I. Otti and Ezenwaji E. E., "Enhancing Community-Driven Initiative in Rainwater Harvesting in Nigeria,” Int. J. Eng. Technol., vol. 3, no. 1, pp. 73-79, 2013.

[3] S. Jain, P. Thakur, S. Singh, and M. Srivastava, "Design of Rooftop Rainwater Harvesting Tank for Katpadi Region, Tamil Nadu,” SSRG Int. J. Civ. Eng., vol. 2, no. 7, pp. 6-8, 2015.

[4] A. K. Dwivedi, V. B. Patil, and A. B. Karankal, "Rooftop Rain Water Harvesting for Groundwater Recharge in an Educational Complex,” Glob. J. Res. Eng. Civ. Struct. Eng., vol. 13, no. 1, 2013.

[5] Dinas Pekerjaan Umum Kabupaten Pamekasan, "Jumlah Curah Hujan dan Hari Hujan di Setiap Stasiun tahun 2013. Pamekasan,” Pamekasan, 2014.

[6] J. Casalí et al., "Sediment production and water quality of watersheds with contrasting land use in Navarre (Spain),” Agric. Water Manag., vol. 97, no. 10, pp. 1683-1694, Oct. 2010.

[7] T. H. Thomas and D. B. Martinson, Roofwater harvesting : a handbook for practitioners. IRC International Water and Sanitation Centre, 2007.

[8] Sugiharto, Dasar-Dasar Pengolahan Air Limbah. Jakarta: Universitas Indonesia Press, 2008.

[9] K. Foxon, S. Pillay, T. Lalbahadur, N. Rodda, F. Holder, and C. Buckley, "The anaerobic baffled reactor (ABR): An appropriate technology for on-site sanitation,” Water SA, vol. 30, no. 5, pp. 44-50, Dec. 2007. 